\title{
Assessment of agro-ecological influence on the seed quality of groundnut (Arachis hypogaea) in The Gambia
}

\author{
J. A. ADETUMBI*, M. MANGA, D. JALLOW. N. A. AKINTOYE \& T. OMODELE \\ (J.A.A, N.A.A. \& T.O: Institute of Agricultural Research and Training, P.M.B. 5029, Moor \\ Plantation, Ibadan Nigeria; M.M \& D.J.: National Seed Secretariat, Livestock premises, \\ Abuko, P.O. Box 179, Banjul, The Gambia) \\ *Corresponding author's email: jaadetumbi@yahoo.com
}

\begin{abstract}
A survey was conducted to assess the quality of groundnut seed produced and stored under ambient environment across various agro-ecologies of The Gambia, with a view to understanding regions with comparative advantage for its production and storage. Seed production activities of 60 seed growers in 26 communities were collected using structured questionnaires, interviews and observations. The Global Positioning System (GPS) coordinates of the communities were geo-referenced to identify the geographical positioning of the production sites. Samples of the groundnut pods were taken from the seed stores, threshed and subjected to seed quality analysis. Descriptive analysis was used to categorize the seed sources, hectarage cultivated, while seed quality data were subjected to analysis of variance of Nested Design. Means of significant factors were separated using Duncan Multiple Range Test (DMRT) at 5\% significant level. The study showed that groundnut seed production is better concentrated in regions with optimum and sustainable rainfall that will reduce abiotic stress during seed development like the Lower River Region, West Coast Region and Central River Region. Fleur-11 variety was identified as one of the most promising varieties for groundnut cultivation in The Gambia and Tropical Africa.
\end{abstract}

Keywords: Gambia; agro-ecology; groundnut seed; germination; seedling vigour Original scientific paper. Received 24 Feb 2020; revised 7 Sep 2020.

\section{Introduction}

Groundnut (Arachis hypogaea) is a tropical annual legume (Ntare et al., 2008). It is an important oilseed crop of the semi-arid tropics (ICRISAT, 2008), that is also cultivated as food and cash crop in most parts of West Africa (Tarawali \& Queen, 2014). Groundnut seed contains approximately $45 \%$ oil and $30 \%$ protein (Cisse \& Diallo, 2007). The haulms are used as fodder for cattle and other small ruminants. It is the main cash crop of The
Gambia. About $80 \%$ of the population of The Gambia depends on agriculture for its food and cash income. Groundnut is the principal export crop constituting about $66 \%$ of the earnings from agricultural exports. Annual production varied around 151,000 tonnes per annum (Bukhari, 2014).

The farming economy is the only means of income creation for the majority of rural families in the country. The Gambia is located on the West Coast of Africa and has a Sudano-

Ghana Jnl Agric. Sci. 55 (2), $59-69$ 
Sahelian climate, characterized by long dry season and short wet season. The rainfall pattern is used to classify the agro-ecology into three zones namely: Sahelian (less than $600 \mathrm{~mm}$ annually), Sudan-Sahelian (600-900 $\mathrm{mm}$ annually) and Sudan-Guinean zones (900$1200 \mathrm{~mm}$ annually) (FAO, ICRISAT, CIAT, 2018) Crop production in Sudano-Sahelian zones of West Africa is highly vulnerable to various challenges of climate variability, where, smallholder agricultural production is dominated by rain-fed production; a major constraint to crop production in such area is the amount of rainfall and its intra and interannual variability (Traore et al., 2014). This occasionally leads to crop failure and food shortage. A major approach to mitigate food shortage in the face of climate uncertainty is seed security (Hampton et al, 2016). Community seed banks have been reported to have the potentials of improving farmers' resilience and securing access to seeds of locally adapted crops and varieties (Vernooy et al., 2017).

The groundnut seed system in The Gambia has been predominantly informal, until recently and the use of community seed stores has contributed highly to groundnut seed supply in the Country. In recent times, the establishment of seed regulating institutions is making the seed system evolve towards an integrated seed system. This study, therefore, assessed the quality of groundnut seed produced and stored under ambient environment across various agro-ecologies of The Gambia, with a view to understanding regions with comparative advantage for production and storage of quality groundnut seed.

\section{Materials and Methods}

60 seed growers in 26 communities located across the geo-political regions and agro- climatic zones of the country were selected for the study. The selection of the communities was based on the information retrieved from The National Seed Secretariat, the agency responsible for seed industry regulation in the country.

The Global Positioning System (GPS) coordinate of each community was taken using eTrex - Garmin TM GPS tool. The acquired coordinates were geo-referenced to identify the geographical positioning of the surveyed groundnut production sites. In order to identify production sites having extremes of mean annual rainfall and the drought-prone areas, spatial patterns of annual mean rainfall over a minimum period of 20 years was used to highlight secular variability and spatial variations of the selected groundnut production sites.

Data of 2017 seed production activities of the seed growers were collected using interviews and observations according to Harris et al. (1995). The data collected include source of seeds used for production, land area used for production, yield from the production and reason for choice of varieties. Samples of the groundnut pods were taken from the seed stores according to the procedure of ISTA (2003) in April, 2018, when the pods have been stored for about four months under ambient climatic conditions of each agro-ecology based on verbal interview of the seed growers.

The threshing percentage

$$
\text { ( } \left.\frac{\text { Seed weight }}{\text { Seed }+ \text { Pod weight }} \times 100\right)
$$

of each sample was calculated and recorded, after which samples of the seeds were subjected to seed quality analysis as described below:

a. 100 seed weight: This was evaluated by counting randomly selected 100 groundnut seeds in 
three replicates without bias and weighing them using top-loading sensitive balance. The weights were recorded in grammes.

b. Germination percent (GP): Germinating seeds were counted each day beginning from four to eleven days after planting. (ISTA, 2003) when all the viable seeds have germinated. Only normal seedlings that have pronounced shoot and root system were used to calculate the germination percentage as follows:

$$
\mathrm{GP}=\frac{\text { Number of normal germinated seedlings }}{\text { Number of seeds planted }} \times 100
$$

c. Seedling vigor assessment: Seedling vigor of the germinated seedlings was assessed using the seedling vigor parameters suggested by past researchers as follows:

i. Coefficient of velocity of Germination (CVG): This is an estimate of the rapidity of germination of the seed lot and was estimated according to the method described by Al-Ansari and Ksiksi, (2016)

$$
\mathrm{CVG}=\frac{\Sigma N i}{\Sigma N i T i} x 100
$$

Where: $\mathrm{N}$ is the number of seeds germinated each day and $\mathrm{T}$ is the number of days corresponding to $\mathrm{N}$

ii. Seedling Vigor Index (SVI): Seedling length was measured from five randomly selected seedlings of each replicate from the soil level at eleven days after planting. The SVI was then calculated based on method of Adebisi et al, (2008)

$\mathrm{SVI}=\frac{(\text { Germination \% } x \text { seedling length })}{100}$

iii. Mean germination time (MGT) $=$ This is the average number of days taken all the viable seeds to germinate. Lower MGT implies lesser number of days and high vigour. It is calculated based on the method described by AlMudaris (1998),

$$
\text { MGT }=\frac{\Sigma f x}{\Sigma f}
$$

Where $\mathrm{F}$ is the number of seeds germinated on day $\mathrm{x}$.

iv. Seedling mortality (SM): This is the proportion of seedlings that die back before the final day of counting after initial germination. It is estimated based on method of Mibau et al. (2017).

$$
\mathrm{SM}=\frac{\text { Number of dead seedlings }}{\text { Number of germinated seedlings }} \times 100 \text { [5] }
$$

\section{Data analysis}

Descriptive analysis involving categorisation according to seed sources, hectares cultivated, estimated yield was used to characterise the average yield per hectare of the groundnut varieties while data on seed quality were subjected to analysis of variance of Nested Design because all the varieties were not found equally in the same region. Therefore, the region was nested within varieties using SAS version 9 software. Means of significant factors 
were separated using Duncan Multiple Range Test (DMRT) at 5\% significant level.

\section{Results}

Rainfall distribution in the groundnut production sites and regions of The Gambia

The groundnut production sites during this survey were predominantly located in three geo-political (North bank, Upper River, and Central river) regions of the country (Figure 1). Groundnut production is spread across the country with varied quantity of rainfall.
However, majority of the groundnut production communities were within agro-ecologies of low rainfall zones. Eleven communities (42\%) received an annual mean rainfall of between $750-800 \mathrm{~mm}$, followed by seven communities (27\%) that fall within area that received annual mean rainfall of 700-750 mm. (Figure 2). Four communities (16\%) are in the high rainfall area (West Coast Region) of the country and they received above $950 \mathrm{~mm}$ annual mean rainfall (Figure $1 \& 2$ ).

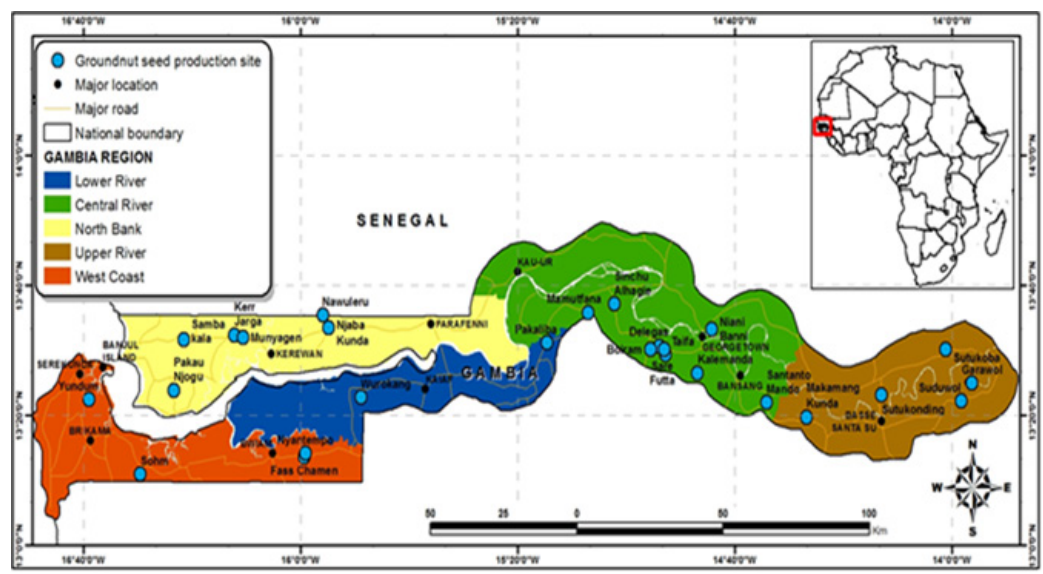

Fig. 1: Groundnut production sites distribution across regions of The Gambia

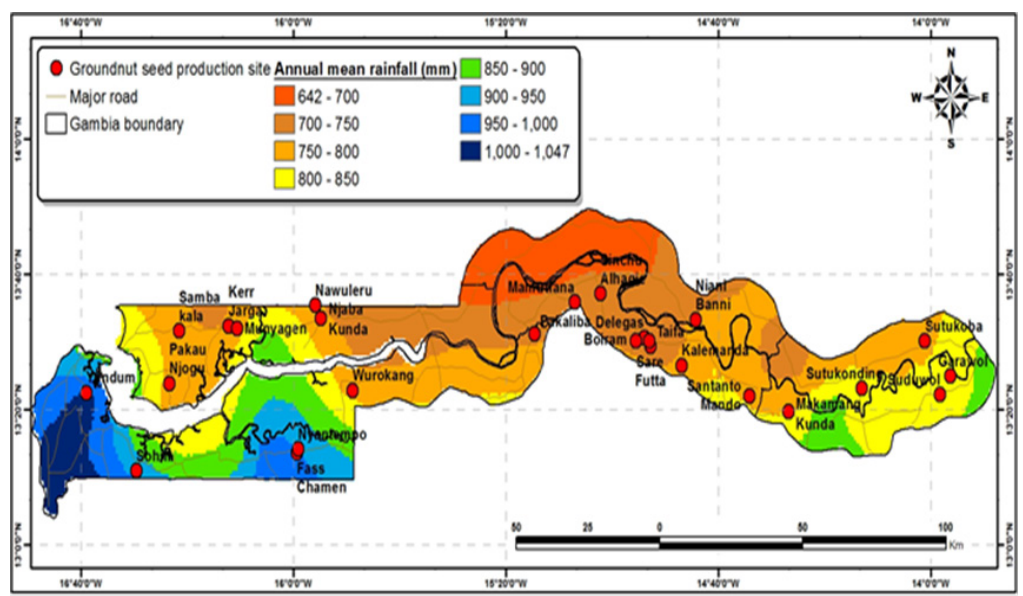

Fig. 2: Mean annual rainfall patterns across the groundnut production sites 
Cultivated groundnut varieties and seed sources

Groundnut pods of five varieties were encountered in the stores of the seed growers across the country during the survey. The varieties include Fleur-11, TS-32-1, GH-11920, 73-33 and S28/206 (Table 1). The variety, Fleur-11 was found with 19 (35\%) seed growers and it was grown on an estimate of 33.5 hectares, with an average yield of 0.8 tons per hectare. This variety is closely followed by varieties $73-33$ and $\mathrm{S} 28 / 206$. The varieties were found with $15(25 \%)$ growers each but was grown on different hectares of land. 7333 was cultivated on an estimated land area of 51 hectares while S28/206 was grown on 60 hectares of land.

Yield estimate of the two varieties is between 1.4 to 1.5 tonnes per hectare. GH$119-20$ and TS-32-1 were found with $6(10 \%)$ and $5(8 \%)$ seed growers respectively. While GH-119-20 was cultivated on 21 hectares with average yield of 1.1 tonnes per hectare, TS-32-1 was cultivated on four hectares and yielded about 0.8 tonnes per hectare. Most of the seed growers used seeds of only one variety for cultivation at a time, but mixtures of two varieties were found with some growers who used farmers saved seed for production.

About $45 \%$ of the seed growers planted the following varieties: Fleur-11, TS32-1 and GH-119-20, which were sourced from the National Seed Secretariat, while $37 \%$ of the seed growers utilized farmers saved seeds for planting 73-33 and S28/206 varieties. About $15 \%$ of the seed growers sourced their seed from the Directorate of Agriculture and only $3 \%$ collected seeds of GH-119-20 varieties from Non-Governmental Organization for their production (Table 1)

TABLE 1

Groundnut varieties in the seed system, sources of seed, land area cultivated and their estimated yield

\begin{tabular}{|c|c|c|c|c|c|c|c|c|}
\hline \multirow{2}{*}{ Varieties } & \multirow[t]{2}{*}{ Total Growers } & \multicolumn{4}{|c|}{ Seed Source } & \multirow{2}{*}{$\begin{array}{c}\text { Land } \\
\text { area } \\
(\mathrm{Ha})\end{array}$} & \multirow{2}{*}{$\begin{array}{c}\text { Total Yield } \\
\text { (Tonnes) }\end{array}$} & \multirow{2}{*}{$\begin{array}{c}\text { Estimated } \\
\text { Yield/ha } \\
\text { (Tonnes) }\end{array}$} \\
\hline & & NSS & $\overline{D o} A$ & $N G O$ & FSS & & & \\
\hline Fleur 11 & $19(35)$ & 18 & 1 & - & - & 33.5 & 25.9 & 0.8 \\
\hline TS-32-1 & $5(8)$ & 5 & - & - & - & 4.0 & 3.0 & 0.8 \\
\hline GH-119-20 & $6(10)$ & 4 & - & 2 & - & 21.0 & 22.8 & 1.1 \\
\hline $73-33$ & $15(25)$ & - & 3 & - & 12 & 51.0 & 74.1 & 1.5 \\
\hline S28/206 & $15(25)$ & - & 5 & - & 10 & 60.0 & 86.5 & 1.4 \\
\hline Total & $60(100)$ & $27(45)$ & $9(15)$ & $2(3)$ & $22(37)$ & 169.5 & 212.3 & 1.3 \\
\hline
\end{tabular}

Values in parentheses are percentages of the numbers in the row and the column.

NSS: National Seed Secretariat, DoA: Directorate of Agriculture, NGO: Non-Governmental Organisation, FSS:

Farmer saved seed 
Determinants of choice of varieties

Responses of the seed growers to various factors that determined their choice of varieties based on farmers request shows that majority of farmers chose groundnut varieties based on the ability of the varieties to produce larger pod size, early maturity and meet certain consumer preferences, among which are kernel flavor, crunchy and crispy seed texture and light coloured seed testa. About $26 \%$ of the seed growers selected their varieties based on the yield potentials of the groundnut varieties as characterized by large pod size.

Early maturity attribute was selected as the reason for choice by $24 \%$ of the seed growers while $22 \%$ selected varieties that hold a promise of meeting the market value of the consumers. High haulm production and canopy cover determined the variety choice of about $16 \%$ of the seed growers while tolerance to drought and high oil content of the varieties determined variety selection for $7 \%$ and $3 \%$ of the seed growers respectively (Table 2).

TABLE 2

Determinant factors that stimulated choice of varieties for production of groundnut

\begin{tabular}{|c|c|c|c|c|c|c|c|}
\hline \multirow[b]{2}{*}{ Varieties } & \multicolumn{6}{|c|}{ Determinant Factors. } & \multirow[b]{2}{*}{ Total } \\
\hline & $\overline{\text { Big Pod }}$ & h haulms & $\begin{array}{c}\text { Early } \\
\text { maturity }\end{array}$ & High market value & $\begin{array}{c}\text { High oil } \\
\text { content }\end{array}$ & $\begin{array}{l}\text { Tolerance } \\
\text { to draught }\end{array}$ & \\
\hline Fleur 11 & - & - & 19 & 19 & - & - & 38 \\
\hline TS-32-1 & - & - & 5 & 5 & - & - & 10 \\
\hline GH-119-20 & 6 & 6 & - & - & 6 & - & 18 \\
\hline $73-33$ & 10 & 13 & 4 & 1 & - & - & 28 \\
\hline S28/206 & 14 & - & - & - & - & 8 & 22 \\
\hline Total & 30 & 19 & 28 & 25 & 6 & 8 & 116 \\
\hline$\%$ of Total & 26 & 16 & 24 & 22 & 5 & 7 & \\
\hline
\end{tabular}

Values are number of seed growers accepting each factor as reason for choice of variety.

One respondent can have more than one reason for choosing a variety.

Variability of seed quality of groundnut varieties across regions

The mean squares of the germination percentage (GP), 100 seed weight, threshing percentage, seedling vigour index (SVI), mean germination time (MGT) and seedling height of the groundnut varieties were significantly different at $\operatorname{Pr}<0.05$, while the seedling mortality, and coefficient of velocity of germination $(\mathrm{CVG})$ of the varieties were not significantly different at $\operatorname{Pr}<0.05$ (Table $3)$. The mean squares of all the seed quality attributes except the seedling mortality were significantly affected by regions of production nested into variety at $\operatorname{Pr}<0.05$ (Table 3 ). 
Assessment of agro-ecological influence on the seed quality...

TABLE 3

Mean square values of seed quality parameters of groundnut varieties grown in different regions of The Gambia

\begin{tabular}{lcccccccc}
\hline sv & GP & $\begin{array}{c}\text { Seedling } \\
\text { mortality }\end{array}$ & 100sw & $\begin{array}{c}\text { Threshing } \\
\text { Percentage }\end{array}$ & SVI & CVG & MGT & $\begin{array}{c}\text { Seedling } \\
\text { height }\end{array}$ \\
\hline Variety (V) & $1599.0^{*}$ & 160.3 & $163.4^{*}$ & $92.1^{*}$ & $80.0^{*}$ & 6.3 & $7.5^{*}$ & $71.4^{*}$ \\
Region (R) & $714.8^{*}$ & 153.4 & $55.2^{*}$ & $103.7^{*}$ & $39.8^{*}$ & $41.2^{*}$ & $3.3^{*}$ & $28.9^{*}$ \\
Error & 270.7 & 250.7 & 18.2 & 26.0 & 7.6 & 10.6 & 1.3 & 6.0 \\
\hline
\end{tabular}

* Significantly different at $\mathrm{Pr}<0.05$

GP: Germination percentage, SVI: Seedling Vigour Index, CVG: Coefficient of Velocity of germination, MGT:

Mean Germination Time.

Means of the seed quality attributes of the groundnut varieties

Means of the seed quality attributes of the groundnut varieties are presented in Table 4. The results indicated significant differences among the means of the groundnut varieties for the studied traits at $5 \%$ probability level. Fleur-11 gave the highest germination percentage $(73 \%)$ that was not significantly different from the GP of S28/206 (66\%) and TS-32-1 (65\%). The lowest GP (49\%) was recorded from GH-119-2 (Table 4).

Seedling mortality of S28/206 (15.8\%) which was the highest, was not significantly different from that of 73-33 (10.6\%) and GH$119-2(7.0 \%)$, but it was significantly different from the other varieties. The lowest seedling mortality was recorded from TS-32-1 (5.1\%) and it was not significantly different from seedling mortality of Fleur-11(5.9\%). GH119-2 recorded significantly highest 100 seed weight $(43.2 \mathrm{~g})$, followed by the 100 seed weight of S28/206 (40.7 g), 73-33 (39.9 g) and TS-32-1(38.4 g) which were not significantly different from each other. The 100 seed weight of Fleur-11 (36.1 g) was the lowest (Table 4)

Highest significant threshing percentage $(72.1 \%)$ was recorded from $73-$ 33. There was no significant difference in the threshing percentage of Fleur-11, S28/206 and TS-32-1, while the lowest threshing percentage $(65.8 \%)$ was from GH-119-2 (Table 4). The seedling vigour index of Fleur-11 (10.1) was significantly higher and different from all other varieties. The SVI of TS-32-1 (8.3) was not significantly different from SVI of S28/206 (6.8), but it was significantly different from the SVI of 73-33 (6.2) and GH-119-2 (5.9). TS32-1 recorded the significantly highest CVG (21.3). There was no significant difference in the CVG of the other varieties.

The mean germination time (MGT) of the varieties was very close to each other, only GH-119-2 recorded significantly lowest MGT (5.6 days). Other varieties germinated after 6 days of planting, with Fleur-11 germinating after 7 days of planting (Table 4).

The seedling height of Fleur-11 (13.7) was the highest, but it was not significantly higher than that of TS-32-1 (12.4), which also was not significantly different from seedling height of GH-119-2 (11.4). The seedling heights of the other varieties (S28/206 and 7333) were not significantly different from each other but different significantly from others (Table 4). 
TABLE 4

Seed Quality Attributes of the Groundout Varieties

\begin{tabular}{lcccccccc}
\hline Variety & $\begin{array}{c}\boldsymbol{G P} \\
(\%)\end{array}$ & $\begin{array}{c}\text { Seedling } \\
\text { mortality } \\
(\%)\end{array}$ & $\begin{array}{c}\text { 100sw } \\
(\boldsymbol{g})\end{array}$ & $\begin{array}{c}\text { Threshing } \\
\text { Percentage } \\
(\%)\end{array}$ & SVI & CVG & $\begin{array}{c}\text { MGT } \\
\text { (days) }\end{array}$ & $\begin{array}{c}\text { Seedling } \\
\text { height } \\
(\mathbf{c m})\end{array}$ \\
\hline Fleur-11 & $73 \mathrm{a}$ & $5.9 \mathrm{~b}$ & $36.1 \mathrm{c}$ & $69.1 \mathrm{~b}$ & $10.1 \mathrm{a}$ & $19.9 \mathrm{ab}$ & $7.2 \mathrm{a}$ & $13.7 \mathrm{a}$ \\
$\mathrm{S} 28 / 206$ & $66 \mathrm{ab}$ & $15.8 \mathrm{a}$ & $40.7 \mathrm{~b}$ & $68.8 \mathrm{~b}$ & $6.8 \mathrm{bc}$ & $19.3 \mathrm{~b}$ & $6.8 \mathrm{ab}$ & $10.0 \mathrm{c}$ \\
TS-32-1 & $65 \mathrm{ab}$ & $5.1 \mathrm{~b}$ & $38.4 \mathrm{~b}$ & $68.3 \mathrm{bc}$ & $8.2 \mathrm{~b}$ & $21.3 \mathrm{a}$ & $6.7 \mathrm{ab}$ & $12.4 \mathrm{ab}$ \\
$73-33$ & $59 \mathrm{~b}$ & $10.6 \mathrm{ab}$ & $39.9 \mathrm{~b}$ & $72.1 \mathrm{a}$ & $6.2 \mathrm{c}$ & $19.3 \mathrm{~b}$ & $6.3 \mathrm{~b}$ & $9.8 \mathrm{c}$ \\
GH-119-2 & $49 \mathrm{c}$ & $7.0 \mathrm{ab}$ & $43.2 \mathrm{a}$ & $65.8 \mathrm{c}$ & $5.9 \mathrm{c}$ & $19.6 \mathrm{ab}$ & $5.6 \mathrm{c}$ & $11.4 \mathrm{~b}$ \\
\hline
\end{tabular}

Means with same letters in same column are not significantly different at $\mathrm{Pr}<0.05$

GP: Germination percentage, SVI: Seedling Vigour Index, CVG: Coefficient of Velocity of germination, MGT:

Mean Germination Time.

Seed quality attributes of groundnut as affected the regions of production

The mean of the seed quality attributes of groundnut seeds produced in each region is presented in Table 5. Germination percentage (GP) of seed produced in LRR (75\%) was the highest but the GP was not significantly different from the GP of the seed produced in WCR $(73 \%)$ and CRR (68\%). GP of seeds produced in the URR (59\%) was the least. The seedling mortality of the seeds produced in all the regions was not significantly different from each other (Table 5).

100 seed weight of seed produced in URR, NBR and CRR were not significantly different from each other. Groundnut seed produced in WCR recorded the least 100 seed weight (34.1g).

URR and CRR gave the highest and second highest significant threshing percentage $(71.4 \%)$ and $(70.6 \%)$ with no significant difference between the two while groundnut seeds from NBR produced the lowest significant threshing percentage $(65.8 \%)$

The result of the effect of the region of production on SVI, CVG and MGT followed the same trend. SVI and CVG of seeds produced in LRR and WCR were not significantly different at $\operatorname{Pr}>0.05$ (Table 5). Also, SVI and CVG of groundnut seed produced in CRR and NBR were not significantly different from each other. URR recorded the lowest and significant SVI (5.9) and CVG (18.1), as well as lowest MGT (6.3) that was not significantly different from MGT of seed produced in NBR and CRR. The seedling height of seed produced in LRR $(15.1 \mathrm{~cm})$ was the highest, but it was not significantly different from seedling height of seed produced in WCR $(14.2 \mathrm{~cm})$. Similarly, seedling height of seeds produced in CRR (12.6 $\mathrm{cm}), \operatorname{NBR}(11.2 \mathrm{~cm})$ and URR $(9.5 \mathrm{~cm})$ was not significantly different at $\operatorname{Pr}>0.05$ (Table 5). 
TABLE 5

Seed Quality Attributes of the Groundout as affected by Regions of production

\begin{tabular}{lcccccccc}
\hline Region & $\boldsymbol{G P}(\%)$ & $\begin{array}{c}\text { Seedling } \\
\text { mortality } \\
(\%)\end{array}$ & $\begin{array}{c}\mathbf{1 0 0} \boldsymbol{s w} \\
(\mathbf{g})\end{array}$ & $\begin{array}{c}\text { Threshing } \\
\text { Percentage } \\
(\%)\end{array}$ & SVI & CVG & $\begin{array}{c}\text { MGT } \\
(\text { days })\end{array}$ & $\begin{array}{c}\text { Seedling } \\
\text { height } \\
(\mathbf{c m})\end{array}$ \\
\hline $\mathrm{LRR}$ & $75 \mathrm{a}$ & $10.9 \mathrm{a}$ & $36.9 \mathrm{~b}$ & $69.4 \mathrm{ab}$ & $11.4 \mathrm{a}$ & $20.7 \mathrm{a}$ & $7.4 \mathrm{a}$ & $15.1 \mathrm{a}$ \\
$\mathrm{WCR}$ & $73 \mathrm{ab}$ & $6.5 \mathrm{a}$ & $34.1 \mathrm{c}$ & $68.2 \mathrm{ab}$ & $10.7 \mathrm{a}$ & $21.4 \mathrm{a}$ & $7.3 \mathrm{ab}$ & $14.2 \mathrm{ab}$ \\
$\mathrm{CRR}$ & $68 \mathrm{abc}$ & $5.9 \mathrm{a}$ & $38.7 \mathrm{ab}$ & $70.6 \mathrm{a}$ & $8.7 \mathrm{~b}$ & $20.1 \mathrm{ab}$ & $6.9 \mathrm{abc}$ & $12.6 \mathrm{bc}$ \\
$\mathrm{NBR}$ & $63 \mathrm{bc}$ & $8.4 \mathrm{a}$ & $40.5 \mathrm{a}$ & $65.8 \mathrm{~b}$ & $7.3 \mathrm{bc}$ & $20.6 \mathrm{a}$ & $6.6 \mathrm{bc}$ & $11.2 \mathrm{c}$ \\
$\mathrm{URR}$ & $59 \mathrm{c}$ & $14.5 \mathrm{a}$ & $40.3 \mathrm{a}$ & $71.4 \mathrm{a}$ & $5.9 \mathrm{c}$ & $18.1 \mathrm{~b}$ & $6.3 \mathrm{c}$ & $9.5 \mathrm{c}$ \\
\hline
\end{tabular}

Means with same letters in same column are not significantly different at $\mathrm{Pr}<0.05$

GP: Germination percentage, SVI: Seedling Vigour Index, CVG: Coefficient of Velocity of germination, MGT: Mean Germination Time; LRR: Lower River Region, WCR: West Coast Region, CRR: Central River Region; NBR: North bank Region; URR: Upper River Region.

\section{Discussion}

Seed yield and quality respond to environmental conditions during production. Quality of seed reduces with extremely high temperature and water stress at critical times during seed development. Environmental temperature can cause a change in carbon/nitrogen ratio, which may reduce seed protein content, thus reducing seed viability by limiting the seed's ability to supply the amino acids required for protein synthesis during embryo growth (Hampton et al., 2013). Most of the regions in the country received enough minimum rainfall that will sustain the production of quality seed of groundnut. Ajeigbe et al., (2014) has recommended an evenly distributed annual rainfall of between $450 \mathrm{~mm}$ and $1250 \mathrm{~mm}$ per annum for good growth and yield of groundnut in the tropics.

The groundnut variety, Fleur-11 which was mostly grown by seed growers was majorly sourced from the NSS, a government agency regulating the seed industry in the country. The large proportion of seed growers planting the variety is a social indicator of farmers' interest in the variety. This interest can be attributed to its early maturing trait, making the variety adaptable to short rainfall climate predominant in the country. Also, its early maturing trait makes the variety available in the market when old stocks are exhausted and many small scale women gardeners produce the variety during the dry season for marketing. Early maturity has been reported as one of the most important traits sought by farmers in Mali, Niger and Nigeria (Ndjeunga et al., 2008).

The difference in the seed quality traits of the varieties can be attributed to variation in their genetic component. The germination and seedling vigour characters of Fleur-11was better than most of the other varieties, however, the seed size, as reflected in 100 seed weight is smaller and it takes longer time to germinate than other varieties. Nevertheless, the threshing percentage is higher; therefore the variety is likely to give more seed yield as compared with varieties with low threshing percentage. Faye et al. (2016) has reported higher yield performance of Fleur-11 under nutrient and water stress trial in Senegal. Conversely, 
GH-119 which produced the highest 100 seed weight recorded the lowest threshing percentage and seedling vigour index, implying possibility of low seed yield and reduced productivity. This result is in agreement with the report of past researchers that there is an inverse relationship between the seed size and quality attributes of groundnut seed. Rezapour et al. (2013) reported that medium seeds had higher germination percentage, seedling length and seedling dry weight than large seed sizes in soybean. Also, Rastegar and Kandi (2011) stated that small seeds had better germination uniformity, getting reserves more and faster than the larger ones to seedlings in soybean.

The Lower River Region of The Gambia produced groundnut seeds that are significantly higher in quality than most regions. This may be attributed to optimum annual rainfall (between $700-800 \mathrm{~mm}$ ) that is able to sustain good crop growth with enough sunshine to dry the seed.

\section{Conclusion}

This study has demonstrated that groundnut seed production is better concentrated in regions with optimum and sustainable rainfall that will reduce abiotic stress which will hamper the seed quality during seed development. The regions recommended for seed production include LRR, WCR and CRR. The results indicated that the seed qualities of most of the varieties are optimally acceptable for commercial seed production. However, Fleur-11 remains one of the most promising varieties for groundnut cultivation in The Gambia and Tropical Africa.

\section{REFERENCES}

Adebisi, M.A., Ola J.A, Akintobi D.C.A. \& Daniel I.O. (2008) Storage of life of sesame (Sesamum indicum L.) seed under humid tropical conditions. Seed Science and Technology 36, $379-387$.
Ajeigbe H. A, Waliyar F, Echekwu CA, Ayuba K, Motagi BN, Eniayeju D \& Inuwa A. (2014) A Farmer's Guide to Groundnut Production in Nigeria. Patancheru 502 324, Telangana, India: International Crops Research Institute for the Semi-Arid Tropics. p. 36.

Al-Mudaris M.A. (1998) Notes on Various Parameters Recording the Speed of Seed Germination. Journal of Agriculture in the Tropics and Subtropics 99, 141 - 154.

Al-Ansari F. \& Taoufik K. (2016) A Quantitative assessment of germination parameters: The case of Crotalaria persica and Tephrosia apollinea. The Open Ecology Journal 9, 13 -21. DOI: $10.2174 / 1874213001609010013$

Bukhari S. (2014) An analysis of the impacts of rainfall and rainfall variability on cash and food crop production in The Gambia. Global Journal of Quantitative Science 1 (2), 17 -23.

Cisse M. \& Diallo S. (2007) Evaluating performance and yield stability of some groundnut (Arachis hypogaea $L$.) varieties under irrigation in three agro-ecological zones of the Senegal River Valley. In: Bationo A., Waswa B., Kihara J., Kimetu J. (eds) Advances in Integrated Soil Fertility Management in sub-Saharan Africa: Challenges and Opportunities. Springer, Dordrecht. p. 1090.

Faye B., Webber H., Gaiser T., Diop M., OwusuSekyere J. D. \& Naab J. B. (2016) Effects of fertilization rate and water availability on peanut growth and yield in Senegal (West Africa). Journal of Sustainable Development 9 (6), $111-131$.

FAO, ICRISAT, CIAT. (2018) Climate-Smart Agriculture in the Gambia. CSA Country Profiles for Africa Series. International Center for Tropical Agriculture (CIAT); International Crops Research Institute for the Semi-Arid Tropics (ICRISAT); Food and Agriculture Organization of the United Nations (FAO). Rome, Italy. p. 20. 
Harris R.P., Bridger J.C., Sachs C.E. and Tallichet S.E. (1995) Empowering rural sociology. Exploring and linking alternative paradigms in theory and methodology. Rural Sociology 60, $585-606$.

Hampton, J., Conner, A., Boelt, B., Chastain, T., \& Rolston, P. (2016) Climate Change: Seed Production and Options for Adaptation. Agriculture 6 (3), 33. MDPI AG. Retrieved from http://dx.doi.org/10.3390/ agriculture6030033.

Hampton, J.G. Boelt, B.; Rolston, M.P. \& Chastain, T.G. (2013) Effects of elevated $\mathrm{CO} 2$ and temperature on seed quality. Journal of Agriculture Science 151, 154 - 162.

ICRISAT. (2008) ICRISAT West Africa programs' Annual report. 2007. Niger: ICRISAT. p. 52.

ISTA (2003) International Rules for Seed Testing Association (ISTA), Zurich, Switzerland ,1 121.

\section{Ndjeunga J, Ntare B.R, Waliyar F, Echekwu C.A,} Kodio O, Kapran I, Diallo A.T, Amadou A, Bissala H.Y \& Da Sylva A. (2008) Early adoption of modern groundnut varieties in West Africa. Working Paper Series no. 24. Sahelian Center, BP 12404 Niamey, Niger: International Crops Research Institute for the Semi-Arid Tropics. p. 62.
Ntare B. R., Diallo A.T, Ndejenga J. \& Waliyar F. (2008) Groundnut seed production manual. Patancheru 502 324, Andhra Pradesh, India: International Crops Research Institute for the Semi-Arid Tropics (ICRISAT). p. 20.

Rastegar, Z. \& Kandi M.A.S. (2011) The effect of salinity and seed size on seed reserve utilization and seedling growth of soybean (Glycine max L). International Journal of Agronomy and Plant Production 2, 1 - 4 .

Rezapour R, Kazemi-arbat, H., Yarnia M. \& Zafarani-Moattar P. (2013) Effect of seed size on germination and seed vigor of two soybean (Glycine $\max$ L.) cultivars. International Research Journal of Applied and Basic Sciences 4 (11), 3396 - 3401.

Tarawali A. \& Queen D. D. (2014) Performance of groundnut varieties (Arachis hypogea) in two agro-ecologies in Sierra Leone. African Journal of Agricultural Research 9 (19), 1442 - 1448.

Traore, B.; van Wijk, M.T.; Descheemaeker, K.; Corbeels, M.; Rufino, M.C. \& Giller, K.E. (2014) Evaluation of climate adaptation options for Sudano-Sahelian cropping systems. Field Crops Research 156, 63 - 75.

Vernooy R, Sthapit B., Otieno G., Shrestha P. \& Gupta A. (2017) The roles of community seed banks in climate change adaption. Development in Practice 27 (3), 316 - 327. 